\title{
Editorial
}

\author{
Paul P. L. Regtien ${ }^{1}$ \\ ${ }^{1}$ Measurement Science Consultancy, Julia Culpstraat 66, 7558JB Hengelo, The Netherlands
}

Keywords: Acta IMEKO, Editorial

Citation: Paul P.L. Regtien, Editorial, Acta IMEKO, no. 0, December 2011, p. 1, identifier: IMEKO-ACTA-00(2011)-01-01

Editor: Paul Regtien, Measurement Science Consultancy, The Netherlands

Received December 28, 2011; In final form December 29, 2011; Published December 30, 2011

Copyright: (C) 2011 IMEKO. This is an open-access article distributed under the terms of the Creative Commons Attribution 3.0 License, which permits unrestricted use, distribution, and reproduction in any medium, provided the original author and source are credited

Funding: This work was supported by Measurement Science Consultancy, The Netherlands

Corresponding author: Paul P. L. Regtien, e-mail: paul@regtien.net

\section{THE REVIVAL OF ACTA IMEKO}

The first issue of the official publication of IMEKO was published in 1958, the year that IMEKO was founded. The title of this issue was: Acta Imeko 1958 ... Proceedings of the International Measurements Conference ... Budapest 240-30. XI. 1958 ... / [issued by the] Hungarian Sci. Soc. for Measurement \& Automation. [Text in Hungarian, German, Eng. and Fr.].

The issue contains the papers presented at the first IMEKO World Congress, an event that is organized every three years. During many years, the contributions to IMEKO World Congresses were published in Acta IMEKO. Later, the Proceedings of the World Congresses were issued by the organizers as Proceedings, and the name Acta IMEKO disappeared from these printed versions.

The printed proceedings were rapidly replaced by proceedings on CDROM's, and recently on memory sticks. The proceedings of the TC-events followed the same development.

Selected papers from World Congresses and TC events were published in a newly established IMEKO journal "Measurement" which first issue came out in 1983. This journal has been evolved gradually into an international journal (published by Elsevier), with scientific articles not only from IMEKO events but from any scientist working in the field of Measurement and Instrumentation. The limited number of issues per year prevents publication of the many qualified contributions to IMEKO workshops and congresses. This is a major reason for IMEKO to start a new journal, obviously an electronic only journal, and named Acta IMEKO as a modern successor of the original printed versions.

Paul Regtien 